19 Kerrigan DL, Fonner VA, Stromdahl S, Kennedy CE. Community empowerment among female sex workers is an effective HIV prevention intervention: a systematic review of the peer-reviewed evidence from low- and middle-income countries. AIDS Behav 2013; 17: 1926-40.

20 Ghose T, Swendeman DT, George SM. The role of brothels in reducing HIV risk in Sonagachi, India. Qual Health Res 2011; 21: 587-600.

21 Alary M, Mukenge-Tshibaka L, Bernier F, et al. Decline in the prevalence of HIV and sexually transmitted diseases among female sex workers in Cotonou, Benin, 1993-1999. AIDS 2002; 16: 463-70.

22 International Labour Office. Recommendation concerning HIV and AIDS and the world of work, 2010 (no. 200). Geneva: International Labour Office, 2010.

23 Rikspolisstyrelsen. Lag (1998:408) om förbund mot köp av sexuella tjänster. Metodutveckling avseende åtgärder mot prostitution. Av Nord, Anders och Rosenberg, Tomas. Polismyndigheten i Skåne. ALM 42914044/99. 2001. POB -429-4616/99 (in Swedish).

24 Socialstyrelsen. Kännedom om prostitution 1998-1999. Stockholm: Socialstyrelsen, 2000 (in Swedish)
25 Dodillet S, Östergren P. The Swedish Sex Purchase Act: claimed success and documented effects. Decriminalizing prostitution and beyond: practical experiences and challenges; The Hague, The Netherlands; March 3-4, 2011.

26 Abel G. Report of the Prostitution Law Review Committee on the operation of the Prostitution Reform Act 2003. Wellington: Ministry of Justice, 2008.

27 Stridbeck U. Purchasing sexual services in Sweden and The Netherlands: legal regulation and experiences. Oslo: Norwegian Ministry of Justice and the Police, 2004

28 Riksförbundet för homosexuellas, bisexuellas och transpersoners rättigheter. Osynliga synliga aktörer. Hbt-personer med erfarenhet av att sälja och/eller köpa sexuella tjänster. Stockholm: Riksförbundet för homosexuellas, bisexuellas och transpersoners rättigheter, 2011 (in Swedish).

29 La Strada International. Ahead of the vote in the European Parliament on the Report of the Committee on Women's Rights and Gender Equality on sexual exploitation and prostitution and its impact on gender equality (2013/2103(INI)). Amsterdam: La Strada International, 2014

\title{
Ebola: worldwide dissemination risk and response priorities
}

The scale of the current outbreak of Ebola virus disease in west Africa is staggering. Thousands of infections and deaths have been reported in recent months, and unless major changes occur in the situation, incidence of Ebola virus disease has been projected to continue to grow and cumulative incidence to exceed 20000 by November. ${ }^{1} \mathrm{~A}$ humanitarian crisis that stretches far beyond the impact of Ebola virus infections is unfolding in Africa, devastating the health systems and economies in affected countries. ${ }^{2}$ In the present outbreak, most infections remain confined to west Africa, although four cases have been detected outside this region: three cases diagnosed in Dallas, USA (of which one infection was contracted in Liberia and two were associated with nosocomial transmission from the first case), and one case in Madrid, Spain, associated with nosocomial transmission (figure).

In The Lancet, Isaac Bogoch and colleagues ${ }^{3}$ report on the potential for international dissemination of Ebola virus disease. Their assessment of risk for different countries is an advance over previous work, ${ }^{4}$ which analysed flight networks and connectivity, but did not account for passenger flows and final destinations. Because of the assumptions of uniform risk across the population and constant prevalence of infection (whereas, in fact, risk within the population is not likely to be uniform and incidence is doubling every 15-30 days),

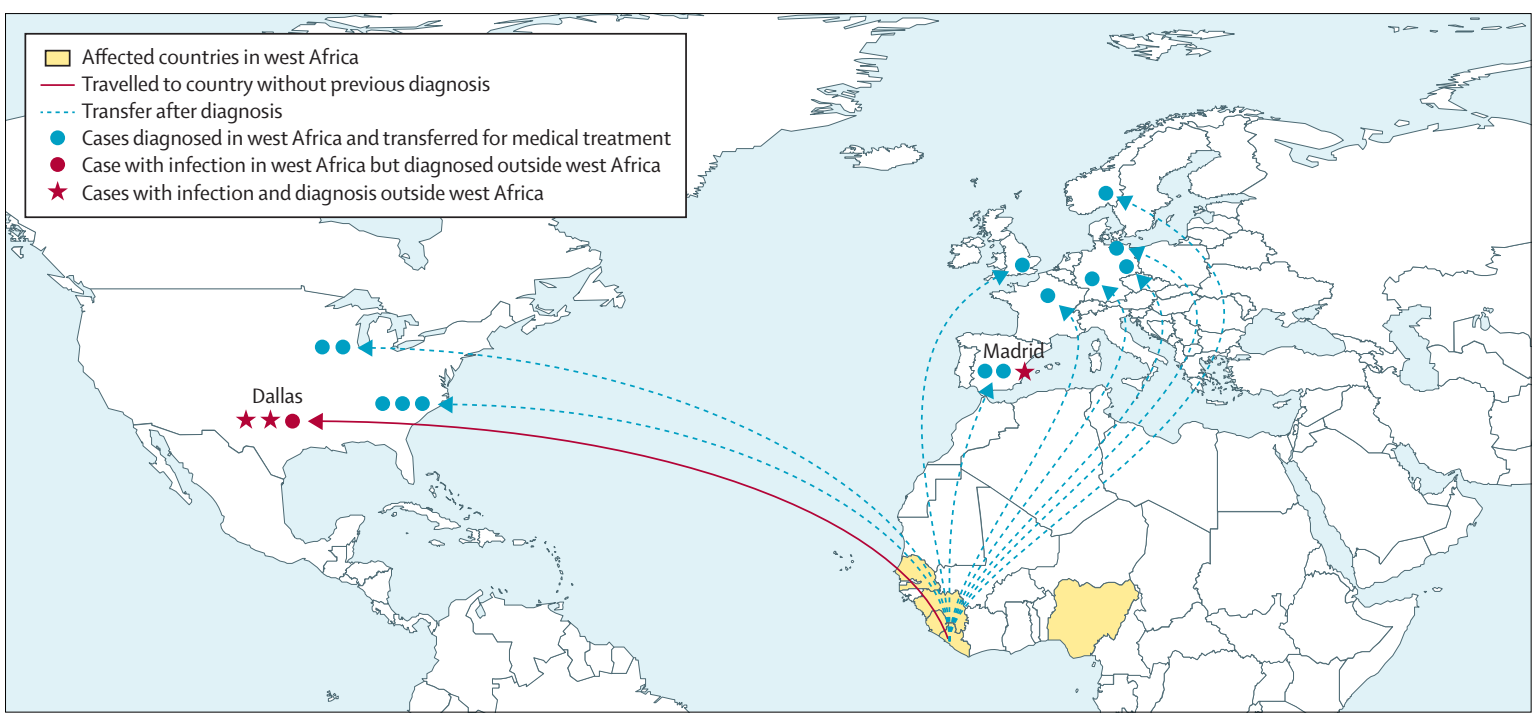

Figure: Geographic location of reported cases of Ebola virus disease as of Oct 16, 2014

Among all reported cases in the 2014 outbreak to date, most infections have been contracted in three countries in west Africa: Guinea, Liberia, and Sierra Leone. 
the relative risks comparing different countries can be more valuable than the estimated absolute risks. Bogoch and colleagues report that the two countries at highest risk of receiving cases are Ghana and Senegal and, outside Africa, the risk for export to the UK or France combined was estimated to be about eight times higher than the risk for export to the USA (15.8 vs 2.0). ${ }^{3}$ In other words, for every case of Ebola virus disease exported to the USA, the authors predict that there will be roughly eight cases exported to the UK or France combined.

Bogoch and colleagues ${ }^{3}$ then studied the potential for exit and entry screening to reduce export of unidentified infections, concluding that exit screening would be a much more efficient approach than entry screening. We would like to add several points to this discussion. First, international support would be essential for implementation of exit screening in the three highly-affected resource-poor countries in west Africa. However, implementation of more stringent checks beyond what is already being done could be very challenging. The affected countries have many urgent priorities-resources including money, personnel, medical equipment, and supplies are urgently needed to expand capacity for detection, diagnosis, and treatment of patients with Ebola virus disease, and to implement isolation and contact tracing, which are currently the best available interventions to control the outbreak. Meanwhile, the outbreak is having a catastrophic effect on the local health-care systems, which were already fragile. $^{2,5}$ No announcements have been made yet about earmarked contributions from the international community to support exit screening.

Second, exit and entry screening might not have a substantial effect on export rates, because of the long incubation period of the disease (average 8-10 days, range 2-21 days) ${ }_{1}^{1}$ combined with rapid disease progression after onset, so that most exportations would be incubating infections missed at border screening points. Finally, a choice is posed between entry and exit screening in Bogoch and colleagues' study, ${ }^{3}$ with exit screening shown to be more efficient than entry screening and the combination of entry and exit screening shown to have little incremental usefulness. However, some countries have implemented and will continue entry screening ${ }^{6,7}$ for various reasons. Subject to entry screening already being implemented, exit screening from the affected countries might not have incremental utility, especially considering the other urgent priorities in the region. In addition to any entry or exit screening, vigilance within countries is essential for early detection of imported cases of Ebola virus disease. ${ }^{3}$

There are several important near-future research needs. Perhaps most urgent is a better understanding of the effectiveness of existing treatment options, including convalescent serum. In the medium term, it is hoped that new vaccines and drugs will be available quickly for human clinical trials and in exposed populations. ${ }^{8}$ The WHO Ebola Response team has neatly summarised the transmission dynamics and epidemiological characteristics including the reproductive number, incubation period, and case fatality risk in the current Ebola virus outbreak, ${ }^{1}$ but one important unknown is the proportion of infections that are asymptomatic or mildly symptomatic. If mild infections do occur and are infectious, disease control outside west Africa might be increasingly challenging. However, this scenario is thought to be unlikely. ${ }^{9}$ One particularly pressing need is for the reassessment of appropriate procedures for infection control, and the potential for the virus to spread via small particle aerosols ${ }^{10}$ in addition to via contact with infected patients or their bodily fluids. Infection of health-care personnel in west Africa is often attributed to the scarcity of appropriate protective equipment and supplies, or inadequate administrative controls. ${ }^{11,12}$ However, the nosocomial cases in Dallas and Madrid have raised the concern that present protocols might not be sufficient to protect health-care personnel fully against infection, particularly if cases are managed in health-care facilities that are not fully prepared.

Benjamin J Cowling, *Hongjie Yu

School of Public Health, Li Ka Shing Faculty of Medicine, The University of Hong Kong, Hong Kong Special Administrative Region, China (BJC); and Division of Infectious Disease, Key Laboratory of Surveillance and Early-warning on Infectious Disease, Chinese Center for Disease Control and Prevention, Beijing 102206, China (HY) yuhj@chinacdc.cn

$\mathrm{BJ} C$ has received research funding from Medlmmune and Sanofi Pasteur, and consults for Crucell. HY declares no competing interests. We thank Ren Xiang, Michael $\mathrm{Ni}$, and Charles Yiu for technical assistance with the figure.

Copyright $($ Cowling et al. Open Access article distributed under the terms of CCBY-NC-SA.

1 WHO Ebola Response Team. Ebola virus disease in west Africa-the first 9 months of the epidemic and forward projections. N EnglJ Med 2014 published online Sept 23. DOI:10.1056/NEJMoa1411100.

2 Piot P, Muyembe JJ, Edmunds WJ. Ebola in west Africa: from disease outbreak to humanitarian crisis. Lancet Infect Dis 2014; published online Oct 2. http://dx.doi.org/10.1016/S1473-3099(14)70956-9. 
3 Bogoch II, Creatore MI, Cetron M, et al. Assessment of the potential for international dissemination of Ebola virus via commercial air travel during the 2014 west African outbreak. Lancet 2014: published online Oct 21. http://dx.doi.org/10.1016/S0140-6736(14)61828-6

4 Gomes MFC, Piontti AP, Rossi L, et al. Assessing the international spreading risk associated with the 2014 west African Ebola outbreak.

PLoS Currents Outbreaks 2014; published online Sept 2. DOI:10.1371/currents. outbreaks.cd818f63d40e24aef769dda7df9e0da5.

5 The Lancet. Ebola: a failure of international collective action. Lancet 2014; 384: 637

6 Centers for Disease Control and Prevention. Press release: enhanced Ebola screening to start at five US airports and new tracking program for all people entering US from Ebola-affected countries. 2014. http://www.cdc.gov/ media/releases/2014/p1008-ebola-screening.html (accessed Oct 10, 2014).

7 Booth R. UK to introduce Ebola screening as death of Briton reported in Macedonia. 2014. http://www.theguardian.com/world/2014/oct/09/ukscreening-airports-ebola-symptoms (accessed Oct 10, 2014)
8 Kanapathipillai R, Restrepo AM, Fast P, et al. Ebola vaccine-an urgent international priority. N Engl/ Med 2014; published online Oct 7. DOI:10.1056/ NEJMp1412166

9 Baxter AG. Symptomless infection with Ebola virus. Lancet 2000; 355: 2178-79.

10 Maclntyre CR, Chughtai AA, Seale H, Richards GA, Davidson PM. Respiratory protection for healthcare workers treating Ebola virus disease (EVD): are facemasks sufficient to meet occupational health and safety obligations? Int J Nurs Stud 2014; 51: 1421-26.

11 Feldmann H, Geisbert TW. Ebola haemorrhagic fever. Lancet 2011; 377: 849-62.

12 Fowler RA, Fletcher T, Fischer WA, 2nd, et al. Caring for critically ill patients with ebola virus disease. Perspectives from west Africa. Am J Respir Crit Care Med 2014; 190: 733-37.

\section{Small-cell lung cancer: local therapy for a systemic disease?}

In The Lancet, Ben Slotman and colleagues report the results of a phase 3 trial of thoracic radiotherapy for small-cell lung cancer. ${ }^{1}$ The trial is the most recent in a long line of studies showing that local radiotherapy benefits patients with small-cell lung cancer, a disease characterised by a bulky intrathoracic mass at presentation, a high propensity for metastasis, and high chemosensitivity, but with a poor prognosis. ${ }^{2}$

Combination of different modalities of cancer treatment offers several advantages. Reduction of the bulk of the tumour will increase blood flow and oxygenation to the tumour. The absence of overlapping toxic effects enables full effective doses of each treatment modality to be maintained, important for surmounting resistance to any one modality. Pignon and colleagues ${ }^{3}$ described a $5 \%$ benefit in survival at 3 years when thoracic radiotherapy was added to induction chemotherapy for patients with limited stage disease. The benefit did not become apparent until about a year after randomisation.

De Ruysscher and co-workers confirmed a postulated interaction between chest irradiation and chemotherapy by showing better long-term survival if the overall treatment time for radiotherapy was shorter than 30 days. ${ }^{4}$ This approach requires concomitant administration of both treatments and accelerated fractionation of radiotherapy. Furthermore, combined treatment modalities enable the eradication of micrometastatic disease in pharmacological sanctuarieseg, the brain. A reduction in the incidence of symptomatic brain metastases and a $6 \%$ benefit in overall survival at 3 years were reported with the sequential addition of prophylactic cranial irradiation in responding patients with stage 1-3 disease..$^{5}$ The European Organisation for Research and Treatment of Cancer reported a doubling of 1-year survival with cranial irradiation in responding patients with extensive stage disease without a deleterious effect on overall health status. ${ }^{6}$

It took several decades and the pooling of data from hundreds of patients to obtain these results, but combined chemotherapy and prophylactic cranial irradiation are now considered the standard of care in many clinical guidelines. The next logical step was to irradiate the tumour bulk in patients with clinically evident metastases. Slotman and colleagues ${ }^{1}$ randomly assigned nearly 500 patients responding to first-line chemotherapy to either standard follow-up or thoracic irradiation consisting of ten fractions of 3 Gy. All patients underwent prophylactic cranial irradiation and no serious toxic effects were reported. Similar to early stage disease, the survival curves separated only at nine months after randomisation, favouring the thoracic radiotherapy group by 18 months. At 2 years, overall survival was $13 \%$ in the group of patients receiving thoracic radiotherapy versus $3 \%$ without radiotherapy; the number needed to treat for one more patient to survive for 2 years was 10.6. Presumably, the competing risk of death caused by extrathoracic metastatic disease that is refractory to chemotherapy becomes less important than the risk caused by uncontrolled disease at the primary site in unirradiated patients at 2 years. Hence, there is an ongoing need for development of novel drugs targeted against molecular alterations in small-cell lung cancer. ${ }^{8}$

The rationale for Slotman and colleagues' study was sound: intrathoracic progression was common in a previous trial of prophylactic cranial irradiation for patients
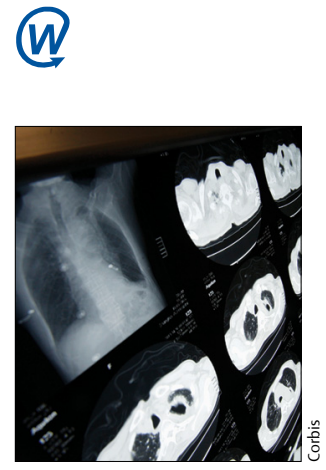

Published Online September 14, 2014 http://dx.doi.org/10.1016/ S0140-6736(14)61252-6 See Articles page 36 